\title{
Conversions of Waste Tube-Tyres (WTT) and Waste Polypropylene (WPP) into Diesel Fuel through Catalytic Pyrolysis Using Base $\mathrm{SrCO}_{3}$
}

\author{
Man Vir Singh
}

\begin{abstract}
Diesel fuels obtained from waste tube-tyre (WTT) and waste polypropylene (WPP) were found using the base strontium carbonate $\left(\mathrm{SrCO}_{3}\right)$ as a catalyst through a catalytic-pyrolysis cracking. Liquid hydrocarbons fuels were analyzed through GCMS-MS, FT-IR, ${ }^{1} \mathrm{H}$ and ${ }^{13} \mathrm{C}$ NMR, ICP. Physicochemical properties of diesel fuel were analyzed through ASTM methods. Their results were found such as saturates, naphthenes, aromatics, monohydric alcohols, aldehydes, esters, amides, halides. Conversions of $95 \mathrm{gm}, 90 \mathrm{gm}$, and $100 \mathrm{gm}$ WPP plastics with $5 \mathrm{gm}, 10 \mathrm{gm}$ and $0 \mathrm{gm} \mathrm{SrCO}_{3}$ into diesel fuel were collected $92 \%$, $89 \%$, and $80 \%$, light gases were $7.52 \%, 10.52 \%$, and $19.45 \%$, residues were $0.48 \%, 0.48 \%$, and $0.55 \%$. Research octane numbers (RON) of diesel fuel from WPP and WTT are 87.32 and 89.65. Conversions of $95 \mathrm{gm}, 90 \mathrm{gm}$, and $100 \mathrm{gm}$ WTT with $5 \mathrm{gm}, 10 \mathrm{gm}$, and $0 \mathrm{gm} \mathrm{SrCO}_{3}$ into diesel fuel were collected $55 \%, 64 \%$, and $48 \%$, light gases were $15.55 \%, 11.64 \%$ and $15.56 \%$, residues were $29.45 \%, 24.36 \%$, and $36.44 \%$. Bromine numbers of diesel fuel from WPP and WTT are $59.87 \%$ and $45.83 \%$.
\end{abstract}

Keywords: Polypropylene; Tube-tyre; Diesel fuel; Catalytic pyrolysis; $\mathrm{SrCO}_{3}$.

Received: 9 November 2020; Accepted: 23 December 2020.

Article type: Research article.

\section{Introduction}

Today the plastic-wastes are increasing day by day because people all over the world have been using some often-familiar plastics used such as LD-PE, HD-PE (Low- and high-density ethylene), PP (Polypropylene), PS (Polystyrene), and PVS (Polyvinyl chloride) which come to be $74 \%$ of the total plastics wastes. ${ }^{[1-2]}$ They have $87 \%$ quantities of 1 to 6 identification codes of categories of waste plastics, their codes of plastics are given by SPI (Society of plastic industry). ${ }^{[3]} 51$ $\%$ of plastics are produced in Asia while $30 \%$ of it is alone produced in China. ${ }^{[4]}$ Presently, plastic production is greater than before all over the globe for over last fifty years. ${ }^{[5]}$ Globally, plastic consumption yearly has inflated sharply from around five million tons from 1950s to almost 280 million tons by 2012; nowadays, manufacturing of plastic has grown 56 times more in the last 62 years ${ }^{[6]}$ and it will reach over 530 million tons in $2020^{[5]}$ Consumptions of virgin plastics are increasing because plastics have become an indispensable part

Department of Chemistry, Singhania University, Pacheri Bari, Rajasthan 333515, India.

E-Mail: manvir24365@gmail.com (M.V.Singh) of everyone is life. ${ }^{[3,20]}$ The plastic requirement such as PP is $19.2 \%$, PE-LD/PE-LLD is $17.2 \%$, HD-PE/PE-MD is $12.1 \%$, PVC is $10.3 \%$, PUR is $7.5 \%$, PS/PS-E are $7 \%$, PET is $7 \%$, and $19.7 \%$ others in Europe ${ }^{[7]}$ All industries are providing premium quality of plastic products because of customers' demands. Therefore, waste plastics slowly degrade because 300 to 500 years are needed for their complete degradation process. ${ }^{[12]}$ Their results are loss of natural-resources, the contribution of global warming due to the contaminated gases $\left(\mathrm{CO}, \mathrm{CO}_{2}, \mathrm{SO}_{2}, \mathrm{NOx}\right)$ release in the environment, and waste plastics are no longer suitable for the environment. ${ }^{[5,7,27-28]}$ The fractions collected from plastics by pyrolysis are very closely similar to fossil fuels because plastics are chemically made from carbon and hydrogen. Some additives are added during the manufacturing of virgin plastics. ${ }^{[8-9]}$ Great efforts are made to find alternative hydrocarbon chemical sources to be used as fuels. Various researchers have primarily focused on waste plastics and tyres into hydrocarbons through the pyrolysis method. ${ }^{[10]}$ Approximately, one ton of the plastics recycled saves $\sim 130$ million $\mathrm{KJ}$ (123 million BTU) which is equivalent to the energy released on combusting $\sim 22$ barrels of fuel. ${ }^{\left[{ }^{[3]}\right.}$ Useful recoveries from plastic wastes are $39.5 \%$ energy and $29.7 \%$ fractions while go to $30.8 \%$ landfill. ${ }^{[12,7]}$ HD-PE (high density polyrthylene) is a very good feedstock for 


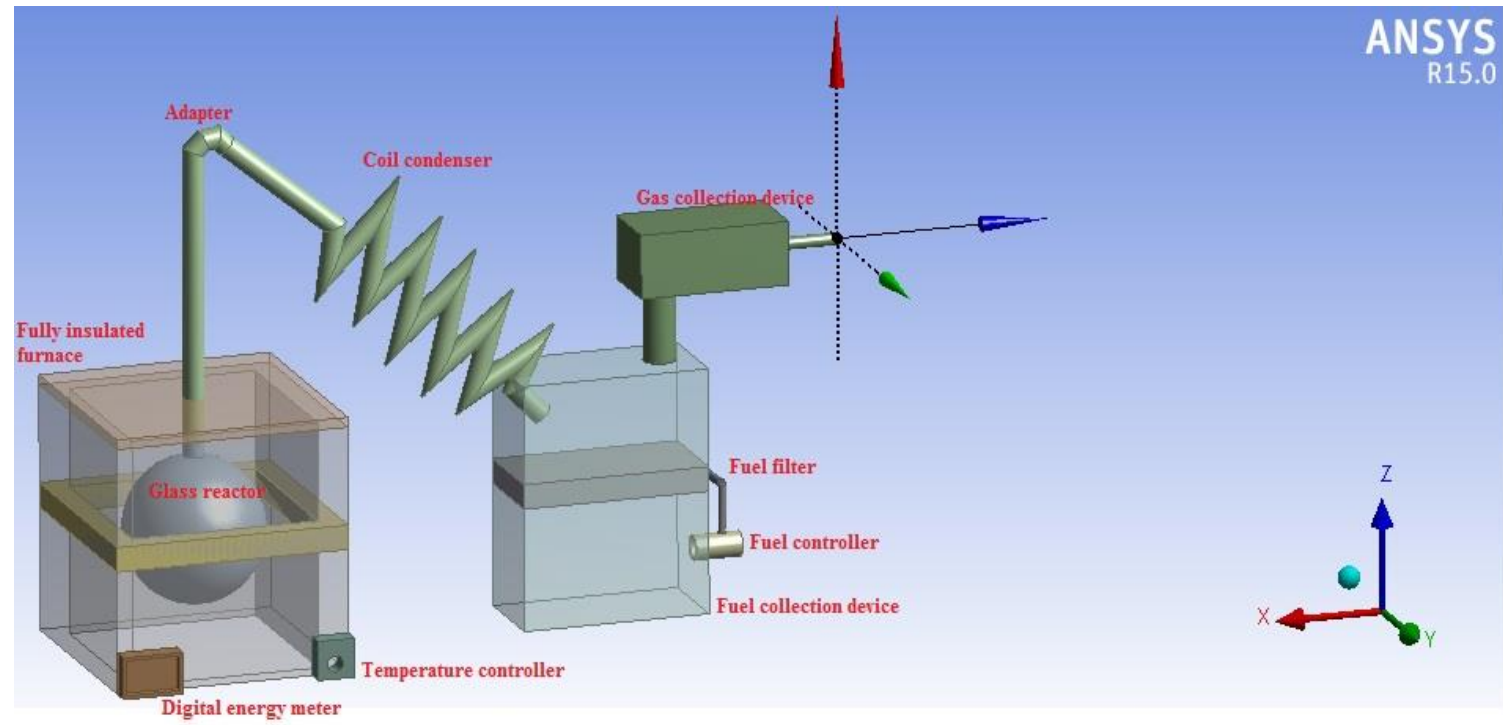

Fig. 1 Catalytic pyrolysis process diagram for WPP and WTT into diesel fuel [12]. Copyright@Royal Society of Chemistry.

pyrolysis process and it's recovery rate is $10 \% \cdot{ }^{[3-11]}$ The technology helps to solve lots of environmental problems when it utilizes plastics waste into valuable energy. The appropriate catalyst can have the good ability to control the quality of fractions with yields, catalytic pyrolysis which is a plastic recycling ${ }^{[5,11]}$ These catalysts include as Singh has used $\mathrm{CoCO} 3$ catalyst for conversation of waste and virgin HD-PE into fuel ${ }^{[5]}$, Singh et al used $\mathrm{CuCO}_{3}$ for waste $\mathrm{HD}-\mathrm{PE}{ }^{[12]}$, Kunwar et al used $\mathrm{MgCO}_{3}$ for HD-PE. ${ }^{[13]}$ Demribas et al used $\mathrm{Na}_{2} \mathrm{CO}_{3}$ with waste-tyre. ${ }^{[14]}$ Shah et al used $\mathrm{CaCO}_{3}$ for waste tyre rubber. ${ }^{[15]} \mathrm{FCC}$, silica-alumina, and zeolites are used in the petroleum refineries for cracking of crude-oil into petroleum fractions. FCC (Fluid catalytic cracking) catalyst came from refineries industry and it's successfully used in pyrolysis cracking process. Presently, FCC catalyst is used for plastics waste such as LD-PE, HD-PE, PP, and PS into liquid hydrocarbons. ${ }^{[11]}$ Devy et al used zeolite ZSM-5 for waste HDPE. ${ }^{[16]}$ Lin et al used spent FCC commercial catalyst for waste polymers and FCC gave higher yield $(82.7 \mathrm{wt} \%)$ than silicate $(14.2 \mathrm{wt} \%){ }^{[17]}$ The economic development rate is indefensible without the saving of hydrocarbons fuel energy. ${ }^{[18-19]}$ Waste plastics have the excellent potential because they are converted 70 to $90 \%$ in liquid fuel during pyrolysis process. Recently, the author used four metal carbonate catalysts to convert plastics into liquid hydrocarbons. The results of the catalyst were very good, so the new $\mathrm{SrCO}_{3}$ catalyst was chosen for further WPP and WTT conversion. $\mathrm{SrCO}_{3}$ catalyst also had good results as well $92 \%$ maximum diesel yield was obtained from $95 \mathrm{gm}$ WPP plastics with $5 \mathrm{gm}$ while the maximum $64 \%$ was obtained from $90 \mathrm{gm}$ WTT with $10 \mathrm{gm} \mathrm{SrCO}_{3}$. The thermal stability of WTT and WPP was decreased due to the presence of a $\mathrm{SrCO}_{3}$ catalyst while without catalyst it was higher. Research is focused on WPP and WTT into fuels using with $\mathrm{SrCO}_{3}$ that could be used by diesel engines and diesel furnaces without any modification. The higher rate of conversion was obtained at mild temperature via pyrolysis catalytic process.

\section{Experiment}

\subsection{Material}

WPP and WTT were collected from near the university mess of the laboratory. WPP was isolated through the help of the SPI code 5, while WTT which is the chemical name of SBR. Collected WPP and WTT were washed with caustic free liquid soap making them totally free from any foreign particles. The wastes were ringed with distilled water and then dried in the presence of sunshine for 10 hours. Dried WPP and WTT were grounded into $<3-4 \mathrm{~mm}^{2}$ size with the help of a grinder machine. $95 \mathrm{gm}, 90 \mathrm{gm}$, and $100 \mathrm{gm}$ WPP plastics were simply blended with $5 \mathrm{gm}, 10 \mathrm{gm}$, and $0 \mathrm{gm}$ base $\mathrm{SrCO}_{3}$ powder (made by CDH Company). Then pyrolysis feedstocks were separately loaded in the glass reactor for the first, second, third experiments process. $95 \mathrm{gm}, 90 \mathrm{gm}$, and $100 \mathrm{gm}$ WTT were simply blended with $5 \mathrm{gm}, 10 \mathrm{gm}$, and $0 \mathrm{gm} \mathrm{SrCO}_{3}$ then it was loaded for the fourth, fifth, six experiments prior to the experiment process. Base $\mathrm{SrCO}_{3}$ powder was analyzed for pore size, volume, and surface area.

\subsection{Experimental Procedure}

All samples of wastes were blended with $\mathrm{SrCO}_{3}$ as a catalyst. Then each sample was separately placed inside a glass reactor for the experiment before starting the process. The diameter of the pyrolysis round-shape glass reactor was $160 \mathrm{~mm}, 158 \mathrm{~mm}$ height, length of the rector-neck was $300 \mathrm{~mm}$, and the wall thickness of the reactor was $3 \mathrm{~mm}$. Later the glass reactor was positioned inside an insulated-furnace. The coil condenser unit was set up with the glass reactor at one end and another finish was added with the fuel collection device. The furnace consists of a digital electricity meter for temperature measurement. The heating temperature of the furnace was controlled from the beginning to the end by a regulator. A furnace started at $23{ }^{\circ} \mathrm{C}$ room temperature; the maximum temperature of pyrolysis was 
$390{ }^{\circ} \mathrm{C}$ and reached $24{ }^{\circ} \mathrm{C} / \mathrm{min}$. It had to yield recoveries of diesel fuel from WTT and WPP by the distillation process. The long chain of WTT (Styrene butadiene) and WPP [-( $\left.\left.\mathrm{C}_{3} \mathrm{H}_{6}\right) n-\right]$ cracked in short-chains (chemical composition of diesel fuels as shown in the Table 4 such as $\mathrm{C}_{n} \mathrm{H}_{2 n+2}, \mathrm{C}_{n} \mathrm{H}_{2 n-6} / \mathrm{C}_{n} \mathrm{H}_{2 n}$, $\mathrm{C}_{\mathrm{n}} \mathrm{H}_{2 \mathrm{n}+1} \mathrm{OH}, \mathrm{C}_{\mathrm{n}} \mathrm{H}_{2 \mathrm{n}+1} \mathrm{CHO}$, RCOOR' esters) during the pyrolysis process and mechanism of plastic degradation has been deeply described by Singh. ${ }^{[21]}$ And their cracked carbon chains came into the vapors phase inside the glass reactor because it had lower molecular weight. After that, it was passed from the beginning to the end of a reactor neck to a condenser. Gases were condensed in the condenser at $23{ }^{\circ} \mathrm{C}$ room temperature then it was collected in fuel collection device, and gases were collected in a gas collection device. Residues were collected in a glass reactor after finishing the experiment process.

\subsection{Analytical Techniques.}

TGA 4000 thermo-gravimetric analyzer (Perkin Elmer) was used to determine for the thermal stability of WPP and WTT. The functional groups of diesel fuels from WPP and WTT were determined with FT-IR spectrometry (Alpha-T Bruker). To further investigate the diesel fuel collected from the degradation of WPP and WTT using a SrCO3 catalyst was analyzed through thermo scientific TSQ 8000 triple quadruple GC-MS-MS system with MS/MS simplicity and even higher performance SRM. Analytical methods of GC-MS-MS are deeply described by man vir singh. ${ }^{[21]}$ Nitrogen adsorptiondesorption determines was performed at liquid $\mathrm{N}_{2}$ analysis gas with a Quantachrome Asiqwin ${ }^{\mathrm{TM}}$. Diesel fuels from WPP and WTT were analyzed by ASTM (American Society for Testing and Materials) method for physicochemical properties such as TAN through an ASTM D 664, TBN through an ASTM D 2896 method, ash content through an IS 1448 (P4) 2008 method, RBCR (On 10\% Residue) through an IS 1448 (P8) 2008 , copper strip corrosion for $3 \mathrm{~h}$ at $100{ }^{\circ} \mathrm{C}$ through IS 1448 (P15) 2004 and ISO, $2160: 1998$ methods, flash point through an IS 1448 (P20) 2007 method, kinematic viscosity at $40{ }^{\circ} \mathrm{C}$ and $100{ }^{\circ} \mathrm{C}$ through an ASTM D 445 methods, density at 15 ${ }^{\circ} \mathrm{C}$ through IS 1448 (P32) 2008 method, sulfur content through a ASTM D 5185 method, $\mathrm{H}_{2} \mathrm{O}$ Content through an ASTM D 1744 method, particles counter through a ISO 4406 method, particles counter through a NAS 1638 method, initial boiling point and final boiling point through an ASTM D 86 method. The bromine number is the amount of the grams of bromine absorbed by 100 grams' sample and is a useful tool to measure aliphatic unsaturation in the gasoline sample. Diesel fuels were analyzed by ICP (Inductively coupled plasma) for 23 types of metal. Diesel fuels were characterized for ${ }^{1} \mathrm{H}$ and ${ }^{13} \mathrm{C}$ NMR (300 MHz).

\section{Results and Discussions}

\subsection{Thermal properties of WTT and WPP for pyrolysis} feedstock

For thermal property as shown in Fig. 2. Temperature-ranges of more degradation of WTT and WPP plastics were found between $340{ }^{\circ} \mathrm{C}$ to $500{ }^{\circ} \mathrm{C}$ and $480{ }^{\circ} \mathrm{C}$ to $510{ }^{\circ} \mathrm{C}$ inside the TGA furnace, nitrogen gas was supplied for inert atmosphere at $20{ }^{\circ} \mathrm{C} / \mathrm{min}$. The heat started from $30{ }^{\circ} \mathrm{C}$ to $700{ }^{\circ} \mathrm{C}$ at $20{ }^{\circ} \mathrm{C} / \mathrm{min}$. This could be useful for investigation of the thermal stability of WTT and WPP plastics. WPP consists of $\mathrm{C} 88 \%, \mathrm{H} 10.2 \%, \mathrm{~N} 0.01 \%$, S $0.1 \%$, O $1 \%$. It was required for the pyrolysis temperature of the furnace. WTT consists of C $86.4 \%$, H $8 \%$, N $0.5 \%$, S $1.7 \%$, O $3.4 \%$. ${ }^{[22]}$

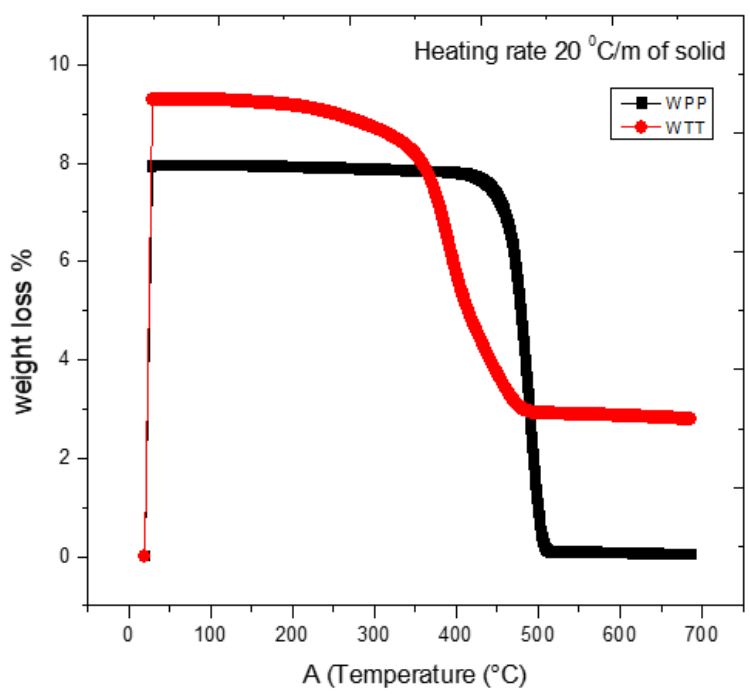

Fig. 2 TGA showing thermal stability of WPP and WTT.

\subsection{Physicochemical properties of diesel fuel from WTT and WPP}

Table 1 shows the physicochemical properties of liquid fuels from WTT and WPP. Physicochemical properties of diesel fuel limit as per IS1460-2005 have been deeply described by man vir et al. ${ }^{[12]}$ All physicochemical properties of the diesel fuel are found to be close to regular diesel; thus, it is appropriate for diesel-engines and diesel furnace. Total acid number and total basic number properties of fuel were measured through a volumetric titration. Ash content, RBCR and copper strip corrosion put for three hours at $100{ }^{\circ} \mathrm{C}$ in fuel samples were evaluated and found to be close to ordinary diesel oil. Flash and fire point were slightly higher than their standard values. Kinematic Viscosity was measured at 40 and $100{ }^{\circ} \mathrm{C}$ through a Kinematic Viscometer Bath and their results were $1.75 \mathrm{cSt}$ and $1.01 \mathrm{cSt}$. Density calculated through a hydrometer and their result was found to be close to ordinary diesel. Sulfur content is also found lower than the ordinary diesel. Chlorine contents were absent. Therefore, dieselengine of an Autorickshaw (Bajaj compact 4S) was run with diesel fuel from WPP and WTT. Yield recoveries of diesel fuels from WTT and WPP by distillation process have been shown in Fig. 3. Diesel recoveries are increasing with rising temperature. Diesel fuel from WPP is more volatile than diesel from WTT. The auto rickshaw engine ran for $3 \mathrm{~km}$ from 150 $\mathrm{ml}$ standard diesel while from $150 \mathrm{ml}$ plastic diesel fuel, it ran for $3.1 \mathrm{~km}$. The most promising substitute for petroleum can 
Table 1 Diesel fuel from WTT and WPP were analyzed for physicochemical properties of diesel.

\begin{tabular}{|c|c|c|c|c|}
\hline Physicochemical properties & $\begin{array}{c}\text { Results of } \\
\text { diesel fuel from } \\
\text { WPP } \\
\end{array}$ & $\begin{array}{l}\text { Results of } \\
\text { diesel fuel } \\
\text { from WTT }\end{array}$ & $\begin{array}{c}\text { Limitations of } \\
\text { standard values [12] }\end{array}$ & $\begin{array}{c}\text { Commercials } \\
\text { values }\end{array}$ \\
\hline TAN & $2.00 \mathrm{mg} \mathrm{KOH} / \mathrm{g}$ & 1.17 & NO & \\
\hline $\mathrm{TBN}$ & $0.30 \mathrm{mg} \mathrm{KOH} / \mathrm{g}$ & 0.21 & NO & \\
\hline Ash content & $0.003 \%$ by wt & 0.003 & 0.01 & \\
\hline RBCR (On 10\% Residue) & $0.024 \%$ by wt & 0.014 & 0.30 maximum & \\
\hline $\begin{array}{c}\text { Copper Strip Corrosion for } \\
33 \text { h at } 100^{\circ} \mathrm{C}\end{array}$ & $1 \mathrm{a}$ & $1 \mathrm{a}$ & $\begin{array}{l}\text { Not worse than } \\
\text { number } 1\end{array}$ & \\
\hline Flash point & $37^{\circ} \mathrm{C}$ & $41{ }^{\circ} \mathrm{C}$ & $35^{\circ} \mathrm{C}$ & $>55$ \\
\hline Fire Point & $53^{\circ} \mathrm{C}$ & $53^{\circ} \mathrm{C}$ & $50^{\circ} \mathrm{C}$ & \\
\hline Kinematic Viscosity at $40^{\circ} \mathrm{C}$ & 1.75 centistokes & 2.01 & NO & \\
\hline Kinematic Viscosity at $100^{\circ} \mathrm{C}$ & 1.01 centistokes & 104 & NO & $2-4.50$ \\
\hline Density at $15^{\circ} \mathrm{C}$ & $0.81 \mathrm{~g} / \mathrm{ml}$ & 0.872 & 820 to $845 \mathrm{Kg} / \mathrm{m}^{3}$ & $82-86$ \\
\hline Sulfur Content & $171.32 \mathrm{ppm}$ & 1.394 & 50 maximum & 1.2 Wight $\%$ \\
\hline $\mathrm{H}_{2} \mathrm{O}$ Content & 354 ppm & 597 & 200 maximum & \\
\hline Particle Counter & $18 / 17 / 15$ & $18 / 17 / 15$ & NO & \\
\hline Particle Counter & 9 & 8 & NO & \\
\hline Initial Boiling Point & $142^{\circ} \mathrm{C}$ & 159 & NO & \\
\hline Final Boiling Point & $318^{\circ} \mathrm{C}$ & 348 & NO & \\
\hline Chlorine content & nil & nil & $\mathrm{NO}$ & \\
\hline
\end{tabular}

be diesel fuels from WTT. Physicochemical properties are found to be closely similar of diesel such as a density is 0.77 $0.84 \mathrm{~g} / \mathrm{cm}^{3}$, a viscosity is $1.74-2.5 \mathrm{~mm}^{2} / \mathrm{s}$, a kinematic viscosity is $1.1-2.27 \mathrm{cSt}$, $\mathrm{HHV}$ is $38-45.86 \mathrm{MJ} / \mathrm{kg}$, a pour point is -9 to $-67^{\circ} \mathrm{C}$, a boiling point is $68-352{ }^{\circ} \mathrm{C}$, and a flash point is $26.1-48^{\circ} \mathrm{C}(5,21,11)$.

NO: Not specified, KOH: potassium hydroxide, PPM: part per million.

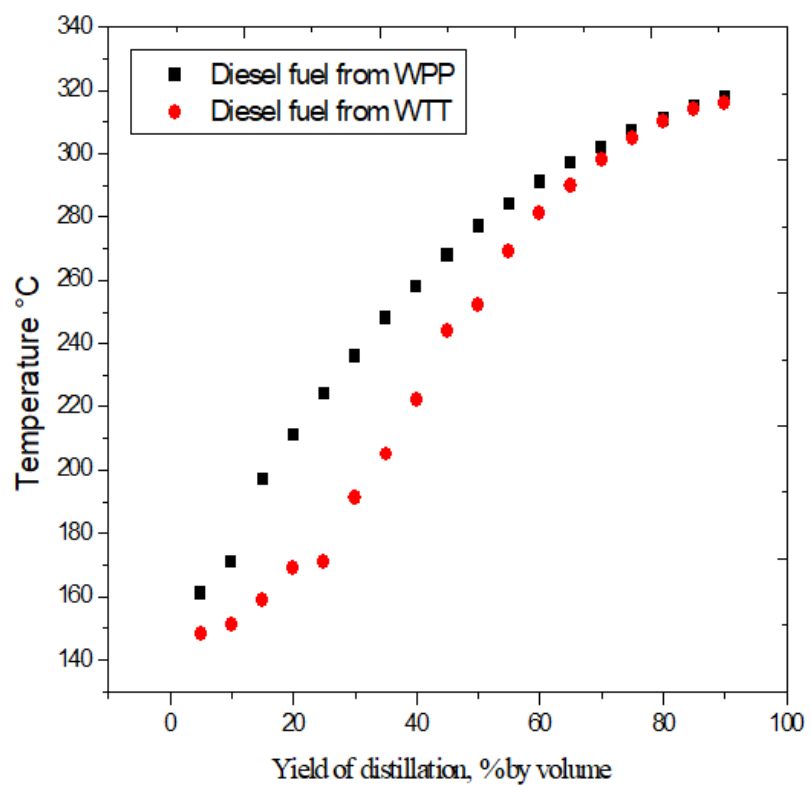

Fig. 3 Distillations properties of diesel fuels obtained from WPP and WTT.
Diesel fuel from WPP and WTT were analyzed by ICP (Inductively coupled plasma) for metal contents. Percentages of metal contents were found less than standard limits and are shown in Table 2.

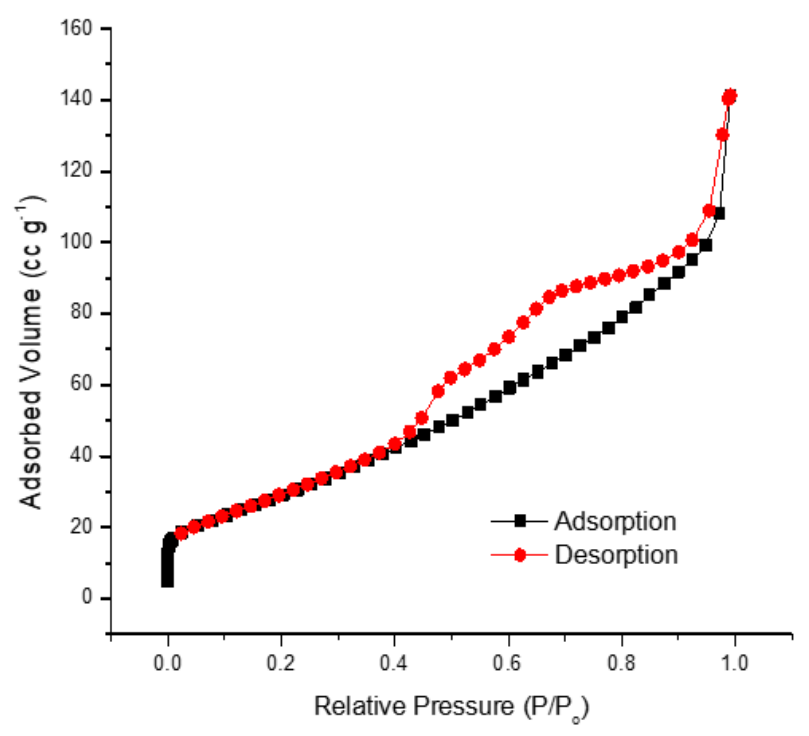

Fig. 4 Showing multi point of BET curves.

\subsection{Characteristics of strontium carbonate $\left(\mathrm{SrCO}_{3}\right)$ catalyst}

As shown in Fig. 4 and 5, the surface area of $\mathrm{SrCO}_{3}$ from BET adsorption data is found to be $114 \mathrm{~m}^{2} \mathrm{~g}^{-1}$. The BET isotherm is obtained when $\mathrm{P} / \mathrm{P}_{0}<1$ and $\mathrm{c}>1$ in the BET equation, where $\mathrm{c}$ is BET constant and $\mathrm{P} / \mathrm{P}_{0}$ partial pressure. The pore 
Table 2 Diesel fuel analyzed by ICP for metal contents.

\begin{tabular}{|c|c|c|c|c|c|c|c|c|c|c|c|c|c|c|c|c|c|c|c|c|c|c|}
\hline \multicolumn{23}{|c|}{ Limits of metal contents in diesel (PPM) ASTM D 5185} \\
\hline $\mathbf{S}$ & $\mathbf{C u}$ & $\mathbf{C a}$ & $\mathbf{K}$ & $\begin{array}{l}\mathbf{N} \\
\mathbf{a}\end{array}$ & $\mathbf{Z n}$ & Cd & $\mathbf{C r}$ & $\begin{array}{l}\mathbf{M} \\
\mathbf{g}\end{array}$ & $\mathbf{F e}$ & $\mathbf{S i}$ & Al & $\mathbf{B}$ & $\mathbf{T i}$ & $\mathbf{V}$ & $\mathbf{N i}$ & Mn & $\begin{array}{l}\mathbf{M} \\
\mathbf{0}\end{array}$ & Sn & $\mathbf{P}$ & $\begin{array}{l}\mathbf{P} \\
\mathbf{b}\end{array}$ & $\begin{array}{l}\text { B } \\
\mathbf{a}\end{array}$ & Ag \\
\hline-- & 15 & -- & 0 & 50 & -- & -- & 5 & -- & 45 & 20 & 10 & -- & -- & -- & 10 & -- & -- & 10 & -- & 20 & - & -- \\
\hline \multicolumn{23}{|c|}{ Percentage of metal contents in diesel from WPP } \\
\hline 171 & 0.0 & 0.0 & 0.8 & 1. & 0.1 & 0.0 & 0.0 & 0 & 0. & 0.0 & 0.2 & 2. & 0.0 & 0. & 0.0 & 0.0 & 0 . & 0.0 & 3. & 0 . & 0 & 0.0 \\
\hline .3 & 13 & 1 & 47 & 08 & 02 & 03 & 08 & 0 & 01 & 53 & 22 & 26 & 04 & 17 & 14 & 01 & 03 & 73 & 8 & 15 & & 1 \\
\hline \multicolumn{23}{|c|}{ Percentage of metal contents in diesel from WTT } \\
\hline 1.3 & 0.0 & 0.0 & 0.8 & 1. & 0.0 & 0.0 & 0.0 & 0 & 0. & 0.0 & 0.1 & 2. & 0.0 & 0. & 0.0 & 0.0 & 0. & 0.0 & 4. & 0. & 0 & 0.0 \\
\hline 94 & 12 & 12 & 36 & 05 & 41 & 03 & 07 & 0 & 01 & 52 & 49 & 52 & 04 & 17 & 14 & 01 & 03 & 72 & 65 & 15 & & 16 \\
\hline
\end{tabular}

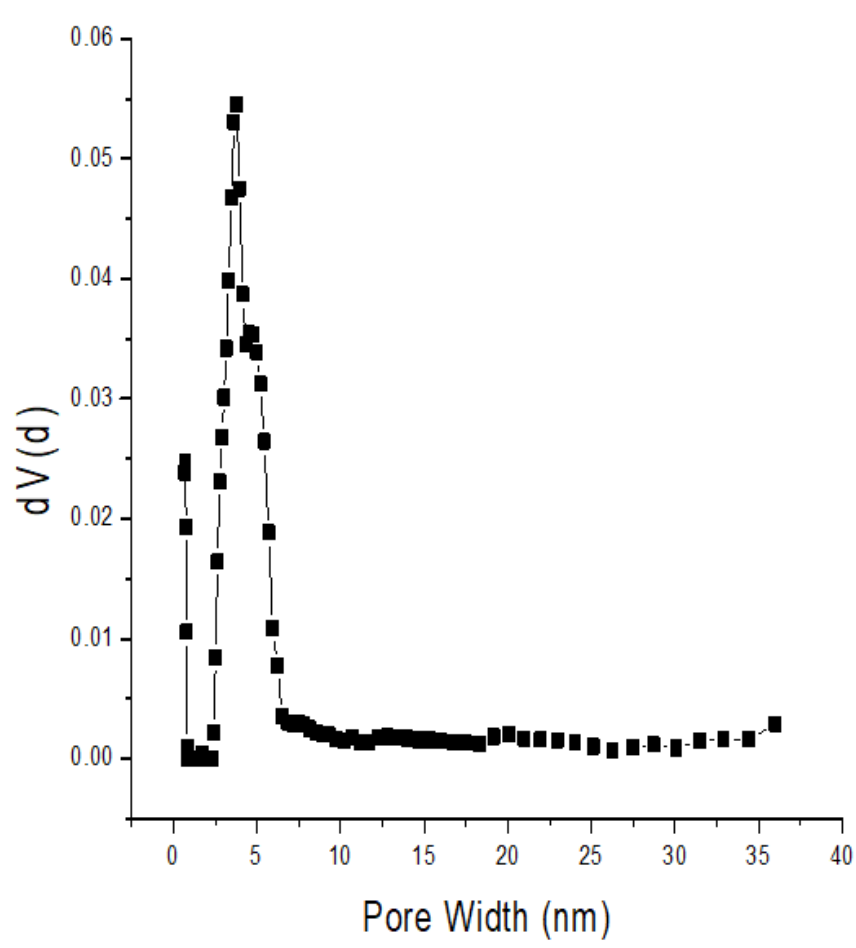

Fig. 5 Showing DFT pore size distribution curve.

size of $\mathrm{SrCO}_{3}$ is found to be $3.79 \mathrm{~nm}$ when nitrogen adsorption isotherm is measured at $77 \mathrm{~K}$. the volume for the $\mathrm{SrCO}_{3}$ catalyst is $0.22 \mathrm{cc} \mathrm{g}^{-1}$ as has been shown in the figure of ecomponent. If higher the surface area of the catalyst is higher, more WTT and WPP plastics could be cracked. ${ }^{[21]}$ During pyrolysis, the thermal stability of WTT and WPP decreases due to the presence of $\mathrm{SrCO}_{3}$ catalyst.

\subsection{Mass recoveries of gases, diesel fuel, and residues from WTT and WPP}

The mass quantity of diesel fuel, gases and residues were collected from $95 \mathrm{gm}, 90 \mathrm{gm} 100 \mathrm{gm}$ waste polypropylene plastic (WPP) with $5 \mathrm{gm}, 10 \mathrm{gm}$, and $0 \mathrm{gm} \mathrm{SrCO}_{3}$ and Obtained liquid yields from WPP and WTT with $\mathrm{SrCO}_{3}$ and has been compared with another metal carbonates catalysts and, are shown in Fig. 6 and Table 3. WPP plastics whose rate of conversion in diesel fuel were $92 \%, 89 \%, 80 \%$ light gases $7.52 \%, 10.52 \%, 19.45 \%$ and residues $0.48 \%, 0.48 \%, 0.55 \%$ at $382{ }^{\circ} \mathrm{C}, 380{ }^{\circ} \mathrm{C}, 389{ }^{\circ} \mathrm{C}$ temperatures. Again, the mass quantity of diesel fuel, gases, and residues were collected from $95 \mathrm{gm}, 90 \mathrm{gm}, 100 \mathrm{gm}$ of WTT plastic with $5 \mathrm{gm}, 10 \mathrm{gm}, 0$ gm $\mathrm{SrCO}_{3}$. WTT whose rates of conversion in diesel fuel were $55 \%, 64 \%, 48 \%$ light gases $15.55 \%, 11.64 \%, 15.56$ and residues $29.45 \%, 24.36 \%, 36.44 \%$ at $370{ }^{\circ} \mathrm{C}, 370{ }^{\circ} \mathrm{C}, 375^{\circ} \mathrm{C}$ temperatures. All recoveries obtained from WPP and WTT have been compared with others as shown in Table 3 .

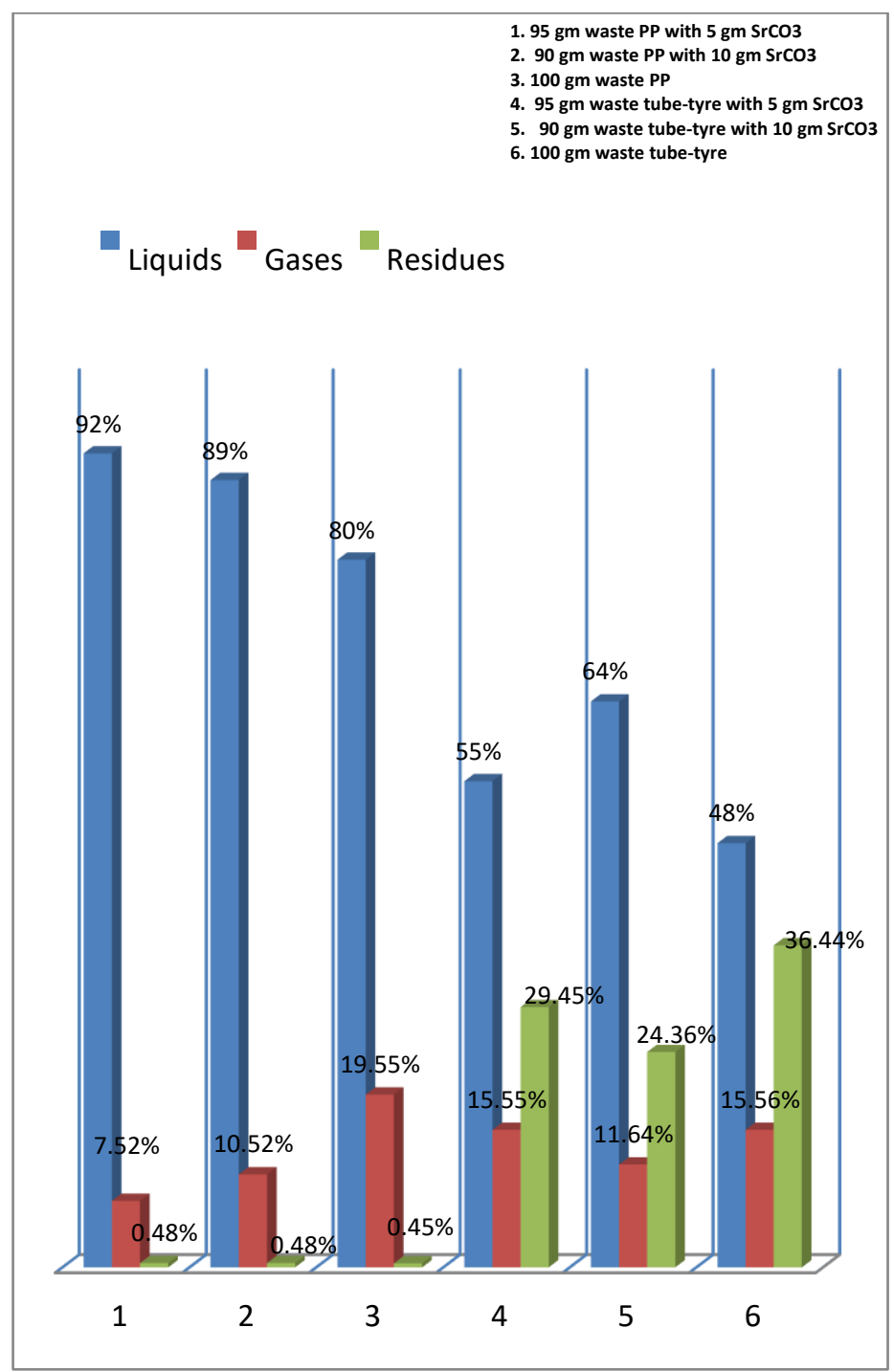

Fig. 6 Fractions of WPP and WTT. 
Table 3 Comparison of collected gases, liquids, and residues from different plastics used with different catalysts.

\begin{tabular}{|c|c|c|c|c|c|c|}
\hline Types of plastic & $\begin{array}{l}\text { Types of } \\
\text { catalyst }\end{array}$ & $\begin{array}{c}\text { Temperature range } \\
\left({ }^{\circ} \mathrm{C}\right)\end{array}$ & $\begin{array}{l}\text { Liquids } \\
(\%)\end{array}$ & $\begin{array}{l}\text { Gases } \\
(\%)\end{array}$ & Residues (\%) & References \\
\hline Virgin HD-PE & $\mathrm{CoCO}_{3} 2 \%$ & 21-395 & 84.40 & 15.35 & 0.25 & [21] \\
\hline Virgin HD-PE & $\mathrm{CoCO}_{3} 5 \%$ & $21-395$ & 88.22 & 11.35 & 0.43 & [21] \\
\hline Virgin HD-PE & $\mathrm{CoCO}_{3} 10 \%$ & 21-395 & 92 & 7.77 & 0.23 & {$[21]$} \\
\hline Waste HD-PE & $\mathrm{CoCO}_{3} 2 \%$ & $21-395$ & 82 & 17.55 & 0.49 & [21] \\
\hline Waste HD-PE & $\mathrm{CoCO}_{3} 5 \%$ & 21-395 & 84 & 15.65 & 0.35 & {$[21]$} \\
\hline Waste HD-PE & $\mathrm{CoCO}_{3} 10 \%$ & $21-395$ & 91 & 8.59 & 0.41 & {$[21]$} \\
\hline Waste HD-PE & $\mathrm{CuCO}_{3} 8 \%$ & $23-390$ & 92 & 7.45 & 0.55 & {$[12]$} \\
\hline Virgin Polypropylene & $\mathrm{NiCO}_{3} 5 \%$ & $23-370$ & 90 & 9.50 & 0.49 & {$[5]$} \\
\hline Virgin Polypropylene & $\mathrm{NiCO}_{3} 10 \%$ & $23-370$ & 89 & 10.45 & 55 & {$[5]$} \\
\hline Waste tyres & $\mathrm{CaCO}_{3}$ & 350 & 32.2 & 32.5 & 35.2 & {$[15]$} \\
\hline $\begin{array}{l}\mathrm{PP}, \mathrm{PE}, \mathrm{PS}, \mathrm{PVC}= \\
\text { weight ratio } 3: 3: 3: 1\end{array}$ & $\mathrm{CaCO}_{3}$ & 430 & 65 & 25 & 10 & [29] \\
\hline Waste tube tyres & $\mathrm{FeCO}_{3}$ & $23-370$ & 56 & 13.55 & 3.45 & {$[30]$} \\
\hline WPP & $\begin{array}{l}\text { Without } \\
\text { catalyst }\end{array}$ & 23-389 & 80 & 19.45 & 0.55 & Present Study \\
\hline WPP & $\mathrm{SrCO}_{3} 5 \%$ & $23-382$ & 92 & 7.52 & 0.48 & Present Study \\
\hline WPP & $\mathrm{SrCO}_{3} 10 \%$ & $23-380$ & 89 & 10.52 & 0.48 & Present Study \\
\hline WTT & $\mathrm{SrCO}_{3} 5 \%$ & $23-270$ & 55 & 15.55 & 24.36 & Present Study \\
\hline WTT & $\mathrm{SrCO}_{3} 10 \%$ & $23-370$ & 64 & 11.64 & 29.45 & Present Study \\
\hline WTT & $\begin{array}{l}\text { Without } \\
\text { catalyst }\end{array}$ & $23-375$ & 48 & 15.56 & 36.44 & Present Study \\
\hline
\end{tabular}

3.5 Analyses of diesel fuel from WTT and WPP with $\mathrm{SrCO}_{3}$ by GC-MS-MS

To further examine the diesel fuel obtained from the WPP plastic and WTT using with a base $\mathrm{SrCO}_{3}$ catalyst was analyzed using with GC-MS-MS, it has been shown in Table 4. The chemical composition of diesel fuel from WTT was $35.21 \%$ of aliphatic $\left(\mathrm{C}_{7}-\mathrm{C}_{20}\right), 47.07 \%$ of aromatics and cyclic hydrocarbons, $0.83 \%$ of amide, $4.59 \%$ of aliphatic hailides, and $8.33 \%$ of monohydric alcohols. The chemical composition of diesel fuel from WPP was $66.19 \%$ of aliphatic $\left(\mathrm{C}_{7}-\mathrm{C}_{20}\right)$, $25.52 \%$ of alkyl hailides, $0.43 \%$ of esters, $0.03 \%$ of aldehydes, $7.42 \%$ of monohydric alcohols, while aromatic compounds were absent. Oxygenates compounds help during the combustion process. Obtained chemical composition is perfectly suitable for diesel fuel. Without a catalyst, $39.6 \%$ oil from waste tires were collected at $458^{\circ} \mathrm{C}$ while $49.2 \%$ oil were collected using a $10 \% \mathrm{Na}_{2} \mathrm{CO}_{3}$ catalyst at $452{ }^{\circ} \mathrm{C}$. ${ }^{[14]} 34.40 \%$ oil from waste tires were collected while and $75.93 \%$ oil from natural rubber was collected at $600{ }^{\circ} \mathrm{C} .80 \%$ aliphatic and $12 \%$ aromatic hydrocarbons were found in oil from natural rubber while $42 \%$ aliphatic and $34 \%$ aromatics in oil from waste rubber. ${ }^{[23]} 73.6 \%$ oil from LD-PE with a mixture of catalysts (kaoline, bentonite, activated charcoal, silica gel) had been collected and their chemical compositions were $67.79 \%$ saturates $7.47 \%$ isoparaffins, $2.92 \%$ naphthalene, 9.63 aromatics, and 12.16 olefins. ${ }^{[24]}$ Total $8.01 \%$ oxygenate compounds were collected in diesel fuel from WPP such as 1Trifluoroacetoxy-10-undecene is $0.13 \%$, monohydric alcohols are $7.42 \%$, aldehyde is $0.03 \%$, and esters are $0.43 \%$. Total $13.1 \%$ oxygenate compounds were collected in diesel fuel from WTT such as esters is $3.94 \%$, monohydric alcohols are $8.33 \%$, and amide is $0.83 \%$.

\subsection{Analyses of diesel fuel from WTT and WPP with $\mathrm{SrCO}_{3}$ through FT-IR}

The functional groups of diesel fuel obtained from WPP and WTT with $\mathrm{SrCO}_{3}$ catalyst were analyzed through FT-IR and it is shown in Table 5. The FT-IR spectrum has provided all functional groups of diesel.

\subsection{Analyses of diesel from WPP and WTT with SrCO3 by ${ }^{1} \mathrm{H}$ and ${ }^{13} \mathrm{C}$ NMR}

Fig. 7 and 8 show the $300 \mathrm{MHz}{ }^{1} \mathrm{H}$ and ${ }^{13} \mathrm{C}$ NMR spectrum of representative diesel fuel from WPP. The NMR for diesel fuel indicates the presence of aliphatic and olefinic protons. Comparison of the ${ }^{1} \mathrm{H}$ NMR and ${ }^{13} \mathrm{C}$ NMR spectrum of diesel fuel with that of the above graph indicates the presence of a large quantity of aliphatic components. 
Table 4 chemical composition of diesel fuel.

Chemical composition of diesel fuel obtained from WTT with SrCO3 catalyst

Chemical composition of diesel fuel obtained from WPP with $\mathrm{SrCO}_{3}$ catalyst

\begin{tabular}{|c|c|c|c|}
\hline Compounds Name & $\begin{array}{r}\text { Area } \\
(\%)\end{array}$ & Compounds Name & Area $(\%)$ \\
\hline $\begin{array}{c}\text { Aromatics/Cyclic Hydrocarbons or } \\
\text { napthene }\end{array}$ & 47.07 & Aliphatics & 66.19 \\
\hline $\begin{array}{c}\text { Cyclobutane, 1,2-bis(1-methylethenyl)-, } \\
\text { trans- }\end{array}$ & 2.51 & 4-Dodecene, (E)- & 2.62 \\
\hline Benzene, 1-ethyl-3-methyl- & 1.37 & Undecane & 2.15 \\
\hline $\begin{array}{l}\text { 1,3-Cyclohexadiene, } 1,3,5,5- \\
\text { tetramethyl- }\end{array}$ & 2.31 & 1-Dodecene & 9.02 \\
\hline $\begin{array}{l}\text { Cyclohexene, 1-methyl-5-(1- } \\
\text { methylethenyl)-, (R)- }\end{array}$ & 23.63 & 4-Nonene, 3-methyl-, (Z)- & 0.02 \\
\hline $\begin{array}{l}\text { Oxazole, 2,5-dihydro-5-(4- } \\
\text { methylphenyl)-4-phenyl- }\end{array}$ & 1.14 & 1-Tridecene & 9.55 \\
\hline $\begin{array}{l}\text { Bicyclo[4.2.1]nona-2,4,7-triene, 9- } \\
\text { (phenylseleno)-, (anti-) }\end{array}$ & 1.08 & Dodecane & 8.93 \\
\hline $\begin{array}{l}\text { 1,3-Cyclopentadiene, } 1,2,3,4- \\
\text { tetramethyl-5-methylene- }\end{array}$ & 0.97 & 6-Tridecene & 0.03 \\
\hline $\begin{array}{l}\text { 1,3,5,7-Cyclooctatetraene, } 1 \text { - } \\
\text { (methoxymethyl)- }\end{array}$ & 1.21 & 9-Octadecene, $(\mathrm{E})$ - & 9.63 \\
\hline $\begin{array}{c}\text { Benzene, (1,2-dicyclopropyl-2- } \\
\text { phenylethyl)- }\end{array}$ & 0.65 & Tetradecane & 5.35 \\
\hline $\begin{array}{l}4 \mathrm{a}, 8 \mathrm{a}- \\
\text { (Methaniminomethano)naphthalene- } \\
\text { 9,11-dione, 10-phenyl- }\end{array}$ & 0.6 & 4-Tetradecene, $(\mathrm{E})$ - & 0.03 \\
\hline \multirow{2}{*}{$\begin{array}{l}\text { 5,8-Etheno-5H-benzocycloheptene- } \\
\text { 6,6,7,7-tetracarbonitrile, } 6,7,8,9- \\
\text { tetrahydro- }\end{array}$} & 2.47 & 1-Nonylcycloheptane & 0.06 \\
\hline & & 10-Heneicosene $(c, t)$ & 11.35 \\
\hline $\begin{array}{c}\text { 1,5-Hexadiene, 3,4-diethyl-1,6- } \\
\text { diphenyl-, (E,E)- }\end{array}$ & 0.68 & 5-Eicosene, $(\mathrm{E})-$ & 7.37 \\
\hline $\begin{array}{l}\text { 1,4-Methanonaphthalene-2,2,3,3- } \\
\text { tetracarbonitrile, 1,4-dihydro-9-(1- } \\
\text { methylethylidene)- }\end{array}$ & 2.44 & 5-Tridecene, $(\mathrm{E})-$ & 0.08 \\
\hline \multirow{2}{*}{$\begin{array}{l}\text { 1,5-Cyclodecadiene, 1,5-dimethyl-8-(1- } \\
\text { methylethylidene)-, (E,E)- }\end{array}$} & 0.78 & Alkyl Hailides & 25.52 \\
\hline & & 1-Iodo-2-methylundecane & 25.39 \\
\hline $\begin{array}{l}\text { Spiro[4.5]dec-7-ene, 1,8-dimethyl-4-(1- } \\
\text { methylethenyl)-, [1S-(1à,4á,5à)]- }\end{array}$ & 0.89 & $\begin{array}{l}\text { 1-Trifluoroacetoxy-10- } \\
\text { undecene }\end{array}$ & 0.13 \\
\hline Hydrazine, tetraphenyl- & 2.97 & Monohydric alcohols & 7.42 \\
\hline N-Benzyl-4-styrylpyridinium chloride & 1.37 & $\begin{array}{l}\text { E-11,13-Tetradecadien-1- } \\
\text { ol }\end{array}$ & 7.39 \\
\hline Esters & 3.94 & Z-10-Pentadecen-1-ol & 0.03 \\
\hline Sulfurous acid, 2-ethylhexyl hexyl ester & 2.86 & Aldehyde & 0.03 \\
\hline Sulfurous acid, butyl heptadecyl ester & 1.08 & cis-7-Decen-1-al & 0.03 \\
\hline Aliphatics & 35.21 & Esters & 0.43 \\
\hline $\begin{array}{c}\text { Cyclopropane, } 1 \text {-(1-methylethyl)-2- } \\
\text { nonyl- }\end{array}$ & 4.15 & $\begin{array}{l}\text { Oxalic acid, cyclobutyl } \\
\text { octadecyl ester }\end{array}$ & 0.02 \\
\hline 2-Undecyne & 0.69 & $\begin{array}{l}\text { Oxalic acid, allyl tridecyl } \\
\text { ester }\end{array}$ & 0.41 \\
\hline Decane, 2,4,6-trimethyl- & 1.34 & & \\
\hline 7-Hexadecene, (Z)- & 6.13 & Total & 99.59 \\
\hline Undecane, 4,7-dimethyl- & 1.26 & & \\
\hline 1,6-Heptadiene, 3,3-dimethyl- & 1.12 & & \\
\hline Decane, 2,4,6-trimethyl- & 1.29 & & \\
\hline
\end{tabular}




$\begin{array}{cc}\text { 10-Heneicosene (c,t) } & 6.58 \\ \text { Undecane, 4,7-dimethyl- } & 1.26 \\ \text { Z-6-Phenyldec-4-en-2-yne } & 1.43 \\ \text { Heptadecane } & 1.37 \\ \text { Eicosane } & 5.35 \\ \text { 2-methylhexacosane } & 0.87 \\ \text { Tetracontane, 3,5,24-trimethyl- } & 0.91 \\ \text { 2-methylhexacosane } & 1.46 \\ \text { Monohydric Alcohols } & \mathbf{8 . 3 3} \\ \text { 1-Dodecanol, 3,7,11-trimethyl- } & 2.96 \\ \text { 1,4-Methanonaphthalen-9-ol, 1,4- } & 0.55 \\ \text { dihydro- } & 4.82 \\ \text { 1-Hexadecanol } & \mathbf{4 . 5 9} \\ \text { Aliphatic halide } & 4.59 \\ \text { 1-Iodo-2-methylundecane } & \mathbf{0 . 8 3} \\ \text { Amide } & 0.83 \\ \text { Furazan-3-carboxamide, 4- } & \mathbf{9 9 . 9 7}\end{array}$

Table 5 functional groups of diesel fuel from WPP and tube-tyre.

\begin{tabular}{|c|c|c|c|}
\hline Wavenumber ${ }^{-1}$ & $\begin{array}{l}\text { Functional groups of diesel fuel from } \\
\text { WPP }\end{array}$ & Wavenumber ${ }^{-1}$ & $\begin{array}{l}\text { Functional groups of diesel } \\
\text { fuel from WTT }\end{array}$ \\
\hline 3077 & terminal (vinyl) $\mathrm{C}-\mathrm{H}$ stretch & 2921 & $\begin{array}{l}\text { methylene } \mathrm{CH}_{2} \quad \text { asym./sym. } \\
\text { stretch }\end{array}$ \\
\hline 2955 & methyl C-H asym./sym. stretch & 2859 & $\mathrm{CH}_{2}$ asym./sym. stretch \\
\hline 2922 & methylene $\mathrm{CH}_{2}$ asym./sym. stretch & 1641 & alkenyl $\mathrm{C}=\mathrm{C}$ stretch \\
\hline 2853 & methylene $\mathrm{CH}$ asym./sym. stretch & 1601 & conjugated $\mathrm{C}=\mathrm{C}$ \\
\hline 1641,1459 & alkenyl $\mathrm{C}=\mathrm{C}$ stretch & 1451 & methylene $\mathrm{C}-\mathrm{C}$ bends \\
\hline 1377 & gem dimethyl $\mathrm{CH}_{3}$ & 1374 & gem dimethyl $\mathrm{CH}_{3}$ \\
\hline 991 & vinyl $\mathrm{C}-\mathrm{H}$ out of plane bend & 1310 & methyne $\mathrm{C}-\mathrm{H}$ bend \\
\hline 964 & trans $\mathrm{C}-\mathrm{H}$ out of plane bend & 1159 & secondary amine, $\mathrm{CN}$ stretch \\
\hline 908 & vinyl C-H out of plan bends & 993 & $\mathrm{C}-\mathrm{H}$ bend \\
\hline 887 & C-H out of plan bends & 884 & vinylidene $\mathrm{C}-\mathrm{H}$ out of plan bends \\
\hline 721 & methylene -(- $\left.\mathrm{CH}_{2}\right)$ n- rocking & 810 & aromatic $\mathrm{C}-\mathrm{H}$ out of plan bends \\
\hline \multirow[t]{2}{*}{636} & thioether $\mathrm{CH}_{3}-\mathrm{S}(\mathrm{C}-\mathrm{S}$ stretch $)$ & 753 & aromatic $\mathrm{C}-\mathrm{H}$ bend \\
\hline & & 697 & aryl thioethers, $-\mathrm{S}(\mathrm{C}-\mathrm{S}$ stretch $)$ \\
\hline
\end{tabular}

The PONA components of aromatics are present albeit in very low concentration as indicated by the NMR spectrum. The signals at $\delta 5.4$ and $\delta 5.8$ further suggest the presence of FCC. The absence of signals around $\delta 3.5-4.2$ indicates that the diesel fuel does not contain oxygenates like iso-propanol, ethanol. From the ${ }^{13} \mathrm{C} \mathrm{NMR}$, it is clear that naphthalene fraction is not present.

\subsubsection{Calculation of bromine number for diesel from WPP} From the above NMR the spectra the bromine number is calculated as indicated below. ${ }^{[25-26]}$

Bromine $\mathrm{No}=\mathrm{K} \mathrm{x}^{\mathrm{H}} \mathrm{I}_{\mathrm{o}} \%$

Where ${ }^{\mathrm{H}} \mathrm{I}_{\mathrm{o}} \%={ }^{\mathrm{H}} \mathrm{I}_{0} /{ }^{\mathrm{H}} \mathrm{I}_{\mathrm{T}} \times 100$

${ }^{\mathrm{H}} \mathrm{I}_{\mathrm{T}}=$ Integral of the region $0.5-8.0 \mathrm{ppm}$

${ }^{\mathrm{H}} \mathrm{I}_{\mathrm{O}}=$ integral of 4.6-6.6 ppm

The value of $K$ is dependent upon the nature of olefins (16.2 for FCC and 9.3 for Coker)

From NMR data of diesel fuel from WPP:

${ }^{\mathrm{H}} \mathrm{I}_{0}=1 ;{ }^{\mathrm{H}} \mathrm{I}_{\mathrm{T}}=27.06$ and $\mathrm{K}=16.2$

Therefore, Bromine No. for diesel fuel from WPP $=59.87 \%$ 


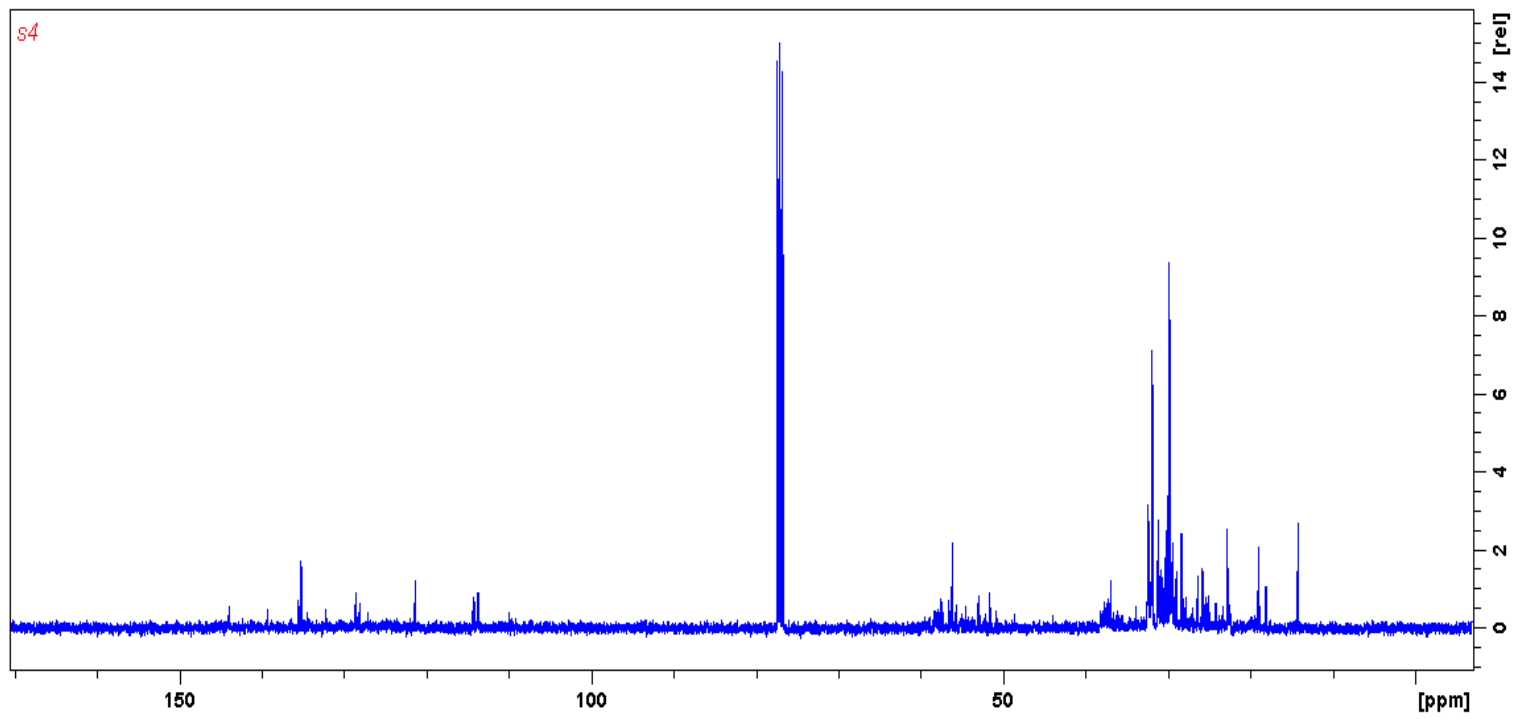

Fig. $7300 \mathrm{MHz}{ }^{13} \mathrm{C}$ NMR spectrum of diesel fuel from WPP.

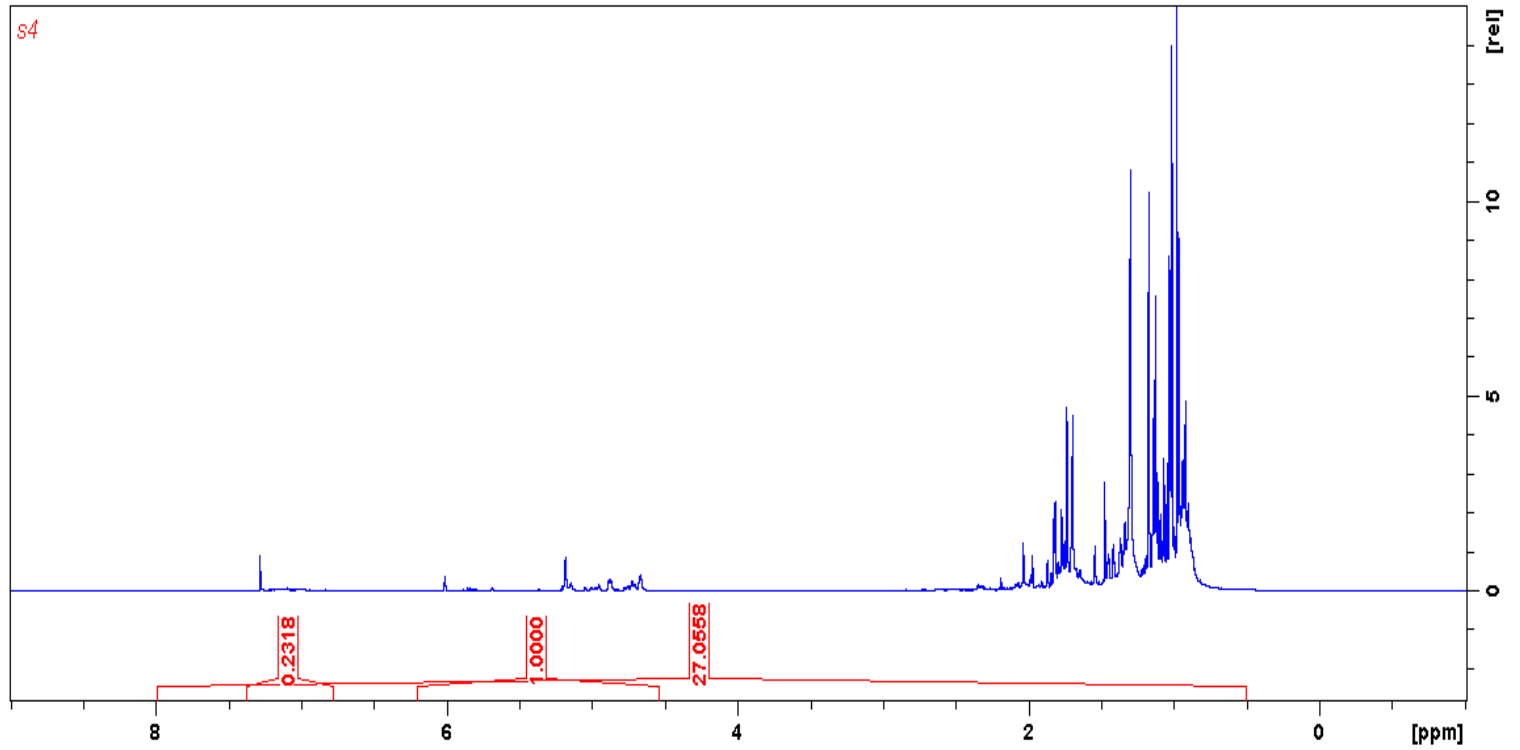

Fig. $8300 \mathrm{MHz}{ }^{1} \mathrm{H}$ spectrum of diesel fuel from WPP.

3.7. 2 Calculation of research octane number of diesel from WPP

Octane number determined by research test is termed as (Research octane number). It is a measure of knock characteristics of the diesel fuel from WPP sample under mild operation condition. It can be calculated by the following NMR method:

$$
\begin{gathered}
\text { RON }(\mathrm{NMR})=83.14+0.48\left(\mathrm{H}_{\mathrm{ar}}\right)+1.02\left(\mathrm{H}_{\text {olf }}\right) \\
\mathrm{H}_{\mathrm{ar}}=\% \text { Aromatic Hydrogen }(6.5-8.0 \mathrm{ppm}) \\
\mathrm{H}_{\text {olf }}=\% \text { Olefinic Hydrogen }(4.5-6.0 \mathrm{ppm})
\end{gathered}
$$

From the above proton NMR it is clear that the \% Aromatic Hydrogen $\left(\mathrm{H}_{\mathrm{ar}}\right)$ is 0.85 and \% Olefinic Hydrogen $\left(\mathrm{H}_{\mathrm{olf}}\right)$ is found to be 3.70. Therefore, RON for diesel fuel from WPP = $83.14+0.48(0.85)+1.02(3.70)=87.32$.

Fig. 9 and 10 show the $300 \mathrm{MHz}{ }^{1} \mathrm{H}$ and ${ }^{13} \mathrm{C}$ NMR spectrum of representative diesel fuel from WTT. The NMR for diesel fuel from WTT indicates the presence of aliphatic, aromatic and olefinic protons. Compare the ${ }^{1} \mathrm{H}$ NMR and ${ }^{13} \mathrm{C}$ NMR spectrum of diesel fuel from WTT with that of literature indicates the presence of a large quantity of aliphatic components. The signals at $\delta 4.5$ and $\delta 5.8$ further suggest the presence of FCC. The absence of signals around $\delta 3.5-4.2$ indicates that the diesel fuel does not contain oxygenates like iso-propanol, ethanol. From the ${ }^{13} \mathrm{C}$ NMR it is clear that naphthalene fraction is not present. The NMR for diesel fuel from WTT indicates predominately aliphatic components. The low-intensity signal at $\delta 7.5$ suggests the presence of aromatics. The NMR spectrum indicates the absence of any Coker component in diesel fuel from WTT. ${ }^{[26]}$

3.7.3 Calculation of bromine number for diesel from WTT From the above NMR spectra, the bromine number is calculated as indicated below. ${ }^{[25-26]}$ 


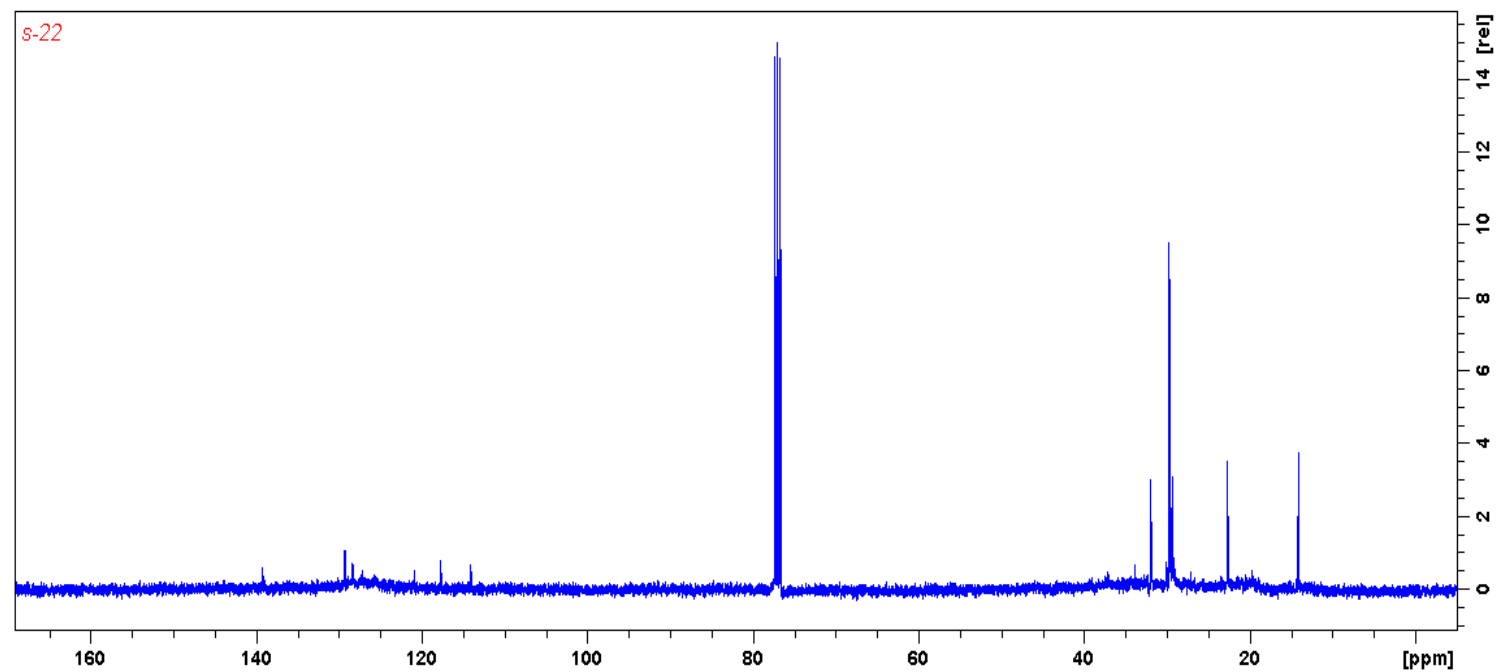

Fig. $9300 \mathrm{MHz}{ }^{13} \mathrm{C}$ NMR spectrum of diesel fuel obtained from WTT.

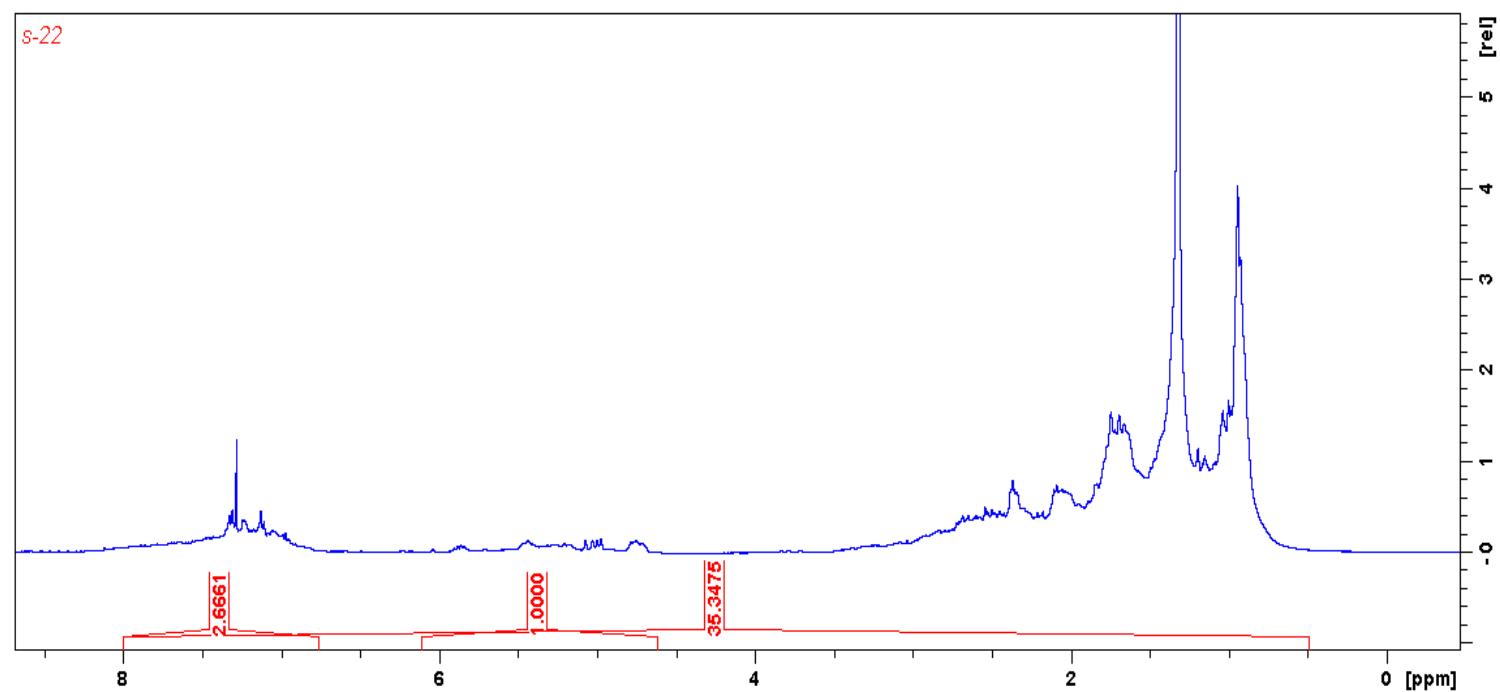

Fig. $10300 \mathrm{MHz}{ }^{1} \mathrm{H}$ NMR spectrum of diesel fuel obtained from WTT.

Bromine $\mathrm{No}=\mathrm{K} \mathrm{x}^{\mathrm{H}} \mathrm{I}_{\mathrm{o}} \%$

Where ${ }^{\mathrm{H}} \mathrm{I}_{\mathrm{o}} \%={ }^{\mathrm{H}} \mathrm{I}_{0} /{ }^{{ }} \mathrm{I}_{\mathrm{T}} \times 100$

${ }^{\mathrm{H}} I_{T}=$ Integral of the region 0.5-8.0 ppm

${ }^{{ }^{H}} I_{O}=$ integral of 4.6-6.6 ppm

The value of $K$ has been found to be dependent upon the nature of olefins (16.2 for FCC and 9.3 for Coker)

From NMR data of diesel fuel obtained from WTT:

${ }^{\mathrm{H}_{\mathrm{I}}} \mathrm{I}_{0}=1 ;{ }^{\mathrm{H}} \mathrm{I}_{\mathrm{T}}=35.35$ and $\mathrm{K}=16.2$

Therefore, Bromine no. for diesel fuel obtained from WTT is $45.83 \%$

\subsubsection{Calculation of research octane number of diesel from WTT}

Research octane number is a measure of knock characteristics of a diesel fuel obtained from WTT under mild operation conditions. It can be calculated by the following NMR method.

$\operatorname{RON}(\mathrm{NMR})=83.14+0.48\left(\mathrm{H}_{\mathrm{ar}}\right)+1.02\left(\mathrm{H}_{\mathrm{olf}}\right)$

$\mathrm{H}_{\mathrm{ar}}=\%$ Aromatic Hydrogen (6.5 -8.0 ppm)

$\mathrm{H}_{\mathrm{olf}}=\%$ Olefinic Hydrogen (4.5 $\left.-6.0 \mathrm{ppm}\right)$

From the above proton NMR, it is clear that the \%
Aromatic Hydrogen $\left(\mathrm{H}_{\mathrm{ar}}\right)$ is 7.55 and \% Olefinic Hydrogen $\left(\mathrm{H}_{\text {olf }}\right)$ is found to be 2.83. Therefore, RON for diesel fuel obtained from WTT $=83.14+0.48(7.55)+1.02(2.83)=$ 89.65

\section{Conclusion}

The research paper aims at solving the problems of environmental pollution due to plastics waste. The need for an alternative fuel source had the catalytic-conversion of WTT and WPP into diesel fuel with a $\mathrm{SrCO}_{3}$. Liquid oil was analyzed through sophisticated instruments such as GC-MSMS, FT-IR, and TGA. The results obtained through a GC-MSMS have been put into five categories as paraffin, napthenes, alcohols, esters, amides, and acetates. Branched-chain and cyclic hydrocarbons were presented in more liquid hydrocarbon fuels from waste; therefore, spontaneously the calorific value of the diesel fuel will be increased. The auto rickshaw (Bajaj compact 4S) ran with diesel fuel which causes less smoke. Diesel fuel is analyzed through all analytical instruments and physicochemical properties of diesel, after 
that it was found to have liquid hydrocarbons equal to diesel fuel; therefore, the diesel engine was run. Diesel fuel was very combustible and flammable. ${ }^{1} \mathrm{H}$ and ${ }^{13} \mathrm{C}$ NMR results have been shown to be saturates, olefins, cyclic/aromatics hydrocarbons. RON and bromine numbers were found to be appropriate in diesel. Diesel was found with very low sulfur contents than the regular fuel.

\section{Supporting Information}

Not applicable

\section{Conflict of interest}

There are no conflicts to declare.

\section{References}

[1] S. Wiwin, G. S. Monica, T. Wega, Triyono, A. Ria, I. F. Iip, Proce. Environ. sci., 2014, 20, 215-224, doi: 10.1016/j.proenv.2014.03.028.

[2] K. Sivagami, G. Divyapriya, R. Selvaraj, P. Madhiyazhagan, N. Sriram, I. Nambi, Pro. Saf. and Envir. Prot., 2020, 149, 497 doi: 10.1016/j.psep.2020.10.038.

[3] A. Rahimi, M. J. García, Nat. Rev. Chem., 2017, 1, 1-12, doi: 10.1038/s41570-017-0046.

[4] S. kumagai, J. nakatani, Y. satto, Y. fukushima, toshiakiyoshioka, J. Jpn Petrol. Inst., 2020, 63, 345-364, doi: 10.1627/jpi.63.345.

[5] M. V. Singh, Indian Chem. Eng., 2018, 61, 254-268, doi: 10.1080/00194506.2018.1548949.

[6] M. A. Hazrat, M. G. Rasul, M. M. K. Khan, A. K. Azad, M. M. K. Bhuiya, Proce. Environ. Scien., 2014, 20, 1681-1685, doi: 10.1016/j.egypro.2014.12.191.

[7] G. Lopez, M. Artetxe, M. Amutio, J. Bilbao, M. Olazar, Renew. Sustain. Energy Rev., 2017, 73, 346-368, doi: 10.1016/j.rser.2017.01.142.

[8] S. M. Al-Salem, A. Antelava, A. Constantinou, G. Manos, A. Dutta, J. environ. Managt., 2017, 197, 177-198, doi: 10.1016/j.jenvman.2017.03.084.

[9] R. K. Mishra, K. Mohanty, Carbon Res. Conv., 2020, 3, 145 155, doi: 10.1016/j.crcon.2020.11.001.

[10] A. K. Fathonatu, P. Yoga, F. Erna, R. Harkam, T. Wega, Proce. Environ. Scien., 2014, 20, 225-234, doi: 10.1016/j.proenv.2014.03.029.

[11] R. Miandad, M. A. Barakat, S. A. Aburiazaiza, M. Rehan, A.S. Nizami, Proc. Saf. Environ. Prot., 2016, 102, 822-838, doi: 10.1016/j.psep.2016.06.022.

[12] M. V. Singh, S. Kumar, M. Sarker, Sust. Energy Fuels, 2018, 2, 1057-1068, doi: 10.1039/C8SE00040A.

[13] B. Kunwar, B. R. Moser, S. R. Chandrasekaran, N. Rajagopalan, B. K. Sharma, Energy, 2016, 111, 884-892, doi: 10.1016/j.energy.2016.06.024

[14] A. Demirbas, B. O. Al-Sasi, A.S. Nizami, Energ. Source. Part A, 2016, 38, 2487-2493, doi: 10.1080/15567036.2015.1052598.

[15] J. Shah, M. R. Jan, F. Mabood, Iran. J. Chem. Chem.Eng., 2008, 27, 103-109.
[16] K. R. Devy, A. N. Mohamad, T. W. Paul, J. Anal. Appl. Pyrol., 2018, 124, 631-637, doi: 10.1016/j.jaap.2016.12.027.

[17] Y. H. Lin, M. H. Yang, Appl. Catal. B-Environ., 2007, 69, 145-153, doi: 10.1016/j.apcatb.2006.07.005.

[18] G. M. Madhukar, K. N. A. kumar, N. S. Lingegowda, Intern. J. Mech. Prod. Eng., 2014, 2, 104-107.

[19] E. Rostek, K. Biernat, J. Sustain. Deve. Energy, water Environ. Syst., 2013, 1, 163-171, doi: 10.13044/j.sdewes.2013.01.0012.

[20] X. Zhang, H. Lei, L. Zhu, M. Qian, G. Yadavalli, J. Wu, S. Chen, Fuel, 2017, 188, 28-38, doi: 10.1016/j.fuel.2016.10.015.

[21] M. V. Singh, J. Anal. Appl. Pyrol., 2018, 134, 151-162, doi: 10.1016/j.jaap.2018.06.003.

[22] A. Rowhani, J. Thomas, Rainey, Energies, 2016, 9, 888-914, doi: 10.3390/en9110888.

[23] I. Julius, Osayi, I. Sunny, O. Michael, Daramola, O. Peter, J. Izak, V. D. Walt, E. Samuel Ogbeide, Chem. Eng. Commun., 2018, 563-5201, doi: 10.1080/00986445.2017.1422493.

[24] A. Soliman, A. F. Hassan, N. E. Nassef, A. Amer, Y. Eltaweel, J. Mater. Cyc. Waste Manage., 2020, 22, 1399-1406, doi: 10.1007/s10163-020-01028-z.

[25] S. Mondal, R. Kumar, V. Bansal, M. B. Patel, J. Anal. Sci. Tech., 2015, 24, 5194-5100, doi: 10.1186/s40543-015-0064-3.

[26] A. S. Sarpal, G. S. Kapur, S. Mukherjee, A. K. Tiwari, Fuel, 2001, 80, 521-528, doi: 10.1016/S0016-2361(00)00123-X.

[27] B. Wang, H. Zheng, D. Zeng, Y. Fu, Y. Qiu, R. Xiao, J. Anal. Appl. Pyrol., 2020, doi: 10.1016/j.jaap.2020.104979.

[28] A. Arregi, M. Seifali A. Abadi, G. Lopez, L. Santamaria, M. Artetxe, J. Bilbao, M. Olazar, ACS Sustain. Chem. Eng., 2020, 8, 17307-17321, doi: 10.1021/acssuschemeng.0c06800.

[29] T. Bhaskar, M. A. Uddin, J. Kaneko, T. Matsui, A. Muto, Y. Sakata, Prog. Rubber plast. Re., 2004, 20, 163-170, doi: 10.1177/147776060402000204.

[30] M. V. Singh, Mater. Today: Proc., 2020, doi: 10.1016/j.matpr.2020.08.689.

\section{Author information}

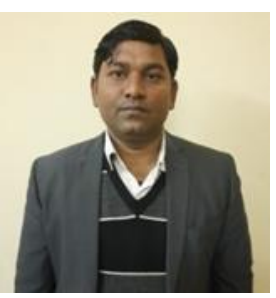

Man Vir Singh is currently working as an Assistant Professor at The Singhania University, jhunjhunu, Rajasthan. He obtained his Ph.D.in 2018 from Bansthali Vidyapith, Tonk, India. He established waste plastics to liquid hydrocarbons lab. He has around 10 publications. His research interest is on Maiterial science, pyrolysis of hydrocarbons, thermal cracking of hydrocarbons, waste plastics to energies, sustainable energy.

Publisher's Note Engineered Science Publisher remains neutral with regard to jurisdictional claims in published maps and institutional affiliations. 